\title{
The Effect of Family Function and Conflict on Family Subjective Well-being with Migrant Husband
}

\author{
Tin Herawati* \\ Department of Family and Consumer Sciences, \\ Faculty of Human Ecology, \\ Bogor Agricultural University \\ Nafi Yuliana Endah \\ Department of Family and Consumer Sciences, \\ Faculty of Human Ecology, \\ Bogor Agricultural University \\ *Corresponding author: tinherawati@ipb.ac.id
}

\begin{abstract}
Poverty, limited employment opportunities, and low rate of labor wage cause couples undergo long distance married because the husband has to work far from the house. This gives impact to family subjective well-being so that the family need to role a family function in order to minimize conflicts. This research aimed to analyze the effect of family function and conflict on family subjective well-being with migrant husband. There were 60 samples in this research which consisted of family with migrant husband teenager children (12-17 years old) in Banyuresmi village, Garut. The wife was the respondent of this research. The sampling technique used here was nonprobability sampling method with form purposive sampling. The data were collected by interviewing the respondents using a questionnaire. The results showed that most of the samples were categorized into families which had good family function, moderate family conflict, and moderate family subjective well-being. Family function affect significantly positive to family subjective well-being. Parental-teenagers conflict affect significantly negative to family subjective well-being.
\end{abstract}

Key words: family conflict, family function, family subjective well-being, migrant husband 


\section{INTRODUCTION}

In 2012-2014, the percentage of poor people in city and village in West Java decreased by average of 0.39 percent and 0.63 percent respectively. Nevertheless, the percentage of poor people in West Java is still dominated by village rather than city (SI, 2014b). According to Widyastuti (2012), a prosperous family can increase the rate of prosperity. This will reduce the total number of poverty in a region. The condition of poverty, lack of employment opportunities, and low rate of labor wage encourage someone to migrate (Leake, 2009). The concept of migration here refers to the concept of circular migration which means the movement of resident out of his village at a particular time to find a job without being followed by resettlement (Djunaedi, 1997). This makes the couple live in a distance because the husband is far away from home. Banovcinova, Levická, and Veres (2014) states that sufficient income make the family function works optimally especially marked by behavioral control that there is no physical violence against family members.

According to Melinda and Prihartanti (2013), a husband and wife who live in a distances could learn to be faithful to spouses and improve the family economy. However, they also found problems such as conflict because they cannot meet, the wife had to take care of and educate their own children without the presence of her husband. According to Puspitawati (2012), the implementation of family functions involved all family members done by dividing task based on shared commitment. According to Adam and Lursen (2001), as cited in Sari (2014), conflicts among parents and teenagers are more common because adolescence is a stage of someone looking for his identity. The result of Sopiah research (2014) stated that family function affects subjective well-being of a family. In addition, the results of Roskos, Handal, and Ubinger (2010) proved that the conflict resolution is negatively related to the level of conflict. Meanwhile, the level of conflict is negatively related to subjective well-being.

Based on data from the Ministry of Religion (2013) the divorce rate in Indonesia increased to 14.6 percent, or 324527 couples. The divorce rate in Garut district continues to increase from year to year. According to the Ministry of Religious Affairs Garut (2013) in Garut divorce rate is as much as 1175 then increased in 2014 with the 1747 figures. Causes vary divorce between the couple to each other. Based on data from the Religious Court Garut (2014) factors causing most dominating divorce is no responsibility, no harmony and economic issues.

Family interaction is determined by the quality of communication and adhesion that occurs between members of the family (Puspitawati, 2012). The interaction in families with a husband would wander distracted because her husband left the house in a long time to work. Less interaction will have an impact on decision making improper. If the interaction within the family will badly degrade the quality of marriage and are at risk for the occurrence of the problems one divorce.

Evrina (2014) stated that one place with few inhabitants migrated namely Garut, West Java, and they wander scattered in various Cities such as Bandung, Tangerang, Bekasi and Jakarta. According to Rizqi (2013), one of the factors that people migrated is economic factors that can not provide for the family. It made 
the couple stay the distance and they still have to run a family function based on a shared commitment. According to Dewi and Basti (2008) that marriage requires adjustment to the demands of the role and responsibilities of each member of the family. The inability to make-such demands could cause discord, disagreement, and even divorce.

The National Population and Family Planning (2013) Data of the Religious Courts the Supreme Court from 2005 to 2010 concluded that an average of one out of ten married couples end up in divorce court and the divorce rate is considered to be the highest in Asia-Africa. Ministry of Religion (2014) stated that the divorce events in Indonesia for last recorded in 2012 amounted to 372577 events, it increased by 38733 or 11 percent of the events in 2011 amounted to 333 844 roomates events. The causes of divorce are economic problems, becoming Indonesian Workers, and infidelity. Ministry of Religion in Garut Subdistrict (2013) stated that the divorce data of Garut subdistrict from 2011 to 2012 increased by 2.54 percent respectively - 1493 and 1747 cases of divorce.

To solve these problems required the family functioning and minimizing the occurrence of family conflicts so as to achieving the subjective well-being of the family. According to Sunarti (2013), it did not achieve the welfare of the family which could cause the family unhappy, did not feel the satisfaction of life, could not grow and developed optimally. Prosperous family certainly is the hope of every family and to achieve this condition each family member must apply a family function (National Population and Family Planning, 2012).

According to Iskandar et al. (2006), there are some factors that affect wellbeing of family, namely age, education, family size, and income. In addition, planning and distribution of tasks within family also affect the well-being of family. Based on this, the study aimed to: (1) identify the characteristics of the family, family function, family conflict, and subjective well-being of families with migrant husbands; and (2) analyze the effect of family conflict on the function and subjective well-being of families with migrant husbands.

\section{RESEARCH METHOD}

This research was designed based on cross sectional study. The research site was selected purposively that was in Banyuresmi Village, Banyuresmi District, Garut Regency. The site was chosen based on an advice from the District Office that the village was categorized into the highest number of migrant husbands. The research was consists of some stages such as preparation, data collection, data processing, data analysis, and report writing.

The population of this study were families with migrant husbands and lived in the Banyuresmi Village. Database as a source of sample was from employee of Banyuresmi District Office. About 60 samples were selected which focused on the family with migrant husband and teenager aged 12-17 years (Hurlock, 1980). The wives were chosen as respondents. Sampling technique used in this study was nonprobability sampling methods in the forms of purposive sampling.

Secondary data used in this study was derived from books, articles, internet, literature and library materials from the results of previous studies. Furthermore, the primary data was derived from interview using a questionnaire to the 
respondents. The question items are as follows: (1) the characteristics of the family (husband and wife) like age, length of education, occupation, family size, and monthly income completed with open-ended questions; (2) the family function like the the function of religion, social, culture, love, protection, reproduction, socialization, education, economy as well as environmental development completed with closed questions. The questionnaire referred to and was modified from National Population and Family Planning (2012), an agency which coordinates family planning in Indonesia, and Sopiah (2014) with the Cronbach's alpha value of 0.878 and it consisted of 80 question items; (3) family conflict like conflict between husband and wife; and parent-child conflicts completed with closed questions. The other questionnaire referred to Sari (2014) with Cronbach's alpha value of 0.908 and it consisted of 34 question items; (4) subjective well-being families with closed questions. The questionnaire referred and was modified from Puspitawati (2012) and Pratama (2014) with Cronbach's alpha value of 0.925 and it consisted of 35 question items.

Family function and family conflict as variables were measured by giving score of 1-3 for one chosen answer like "never", "sometimes", or "often" respectively. Furthermore, subjective well-being family was measured by giving score of 1-3 for one chosen answer like "not satisfied", "satisfied", or "very satisfied" respectively. The total score of each variable was converted into an index score. According to Puspitawati and Herawati (2013), this conversion aimed to unify unit so that the data of each variable can be compared in the similar unit.

The stages of data processing started from editing, entry, cleaning and analyzing. Data analysis was done by the use of software like Microsoft Excel and SPSS (Statistical Product and Service Solution). Processing data using descriptive analysis to identify variables include frequency, standard deviation, minimum value, maximum value, and average. Inferential analysis was used to test the influence (multiple linear regression test) of family characteristics, family function, and family conflicts towards family well-being.

\section{Family Characteristics}

\section{RESULT}

The average age of husband and wife was 44 and 40 years old respectively. The average length of education of husband and wife was 7 years. It can be said that they graduated from elementary school. There were more than three-quarters of total husbands work as a labor $(76.7 \%)$ and the rest were entrepreneur $(23.3 \%)$. Most wives $(80 \%)$ were housewives and the rest were traders $(15 \%)$ and others $(5.1 \%)$. Furthermore, the family size ranged from three to nine persons in one family. Based on family size, National Population and Family Planning (2005) noted that a family which consists of five to seven persons was categorized into moderate family.

The results showed that most husbands worked in Jakarta (43.3\%) and Karawang (16.7\%). Some of them worked in Bandung (8.3\%), Bekasi (5\%), Tangerang (3.3\%), Serang (3.3\%), Bogor (3.3\%), and Sumedang (3.3\%). The rest worked in Purwakarta, Cikarang, Cikampek, Tasik, Ciamis, Ciputat, Tanjung Priok, and Bangka (1.7\% each). In average, the husbands work outside the city for 
almost five weeks. The range of family monthly income was $\mathrm{Rp} 1.000 .000,00$ to Rp8.500.000,00 and the average of family monthly income was Rp2.701.667,00. Based on poverty line reported by BPS (2014a), the average of monthly income per capita considered not poor was Rp547.946,00. However, there was 30 percent of family monthly income per capita categorized as almost poor and 18.3 percent as poor (Table 1$)$.

Table 1 Distribution of the family based on family size and income per capita per month

\begin{tabular}{|c|c|c|}
\hline Family characteristics & $\mathrm{n}$ & $\%$ \\
\hline \multicolumn{3}{|l|}{ Family sizes } \\
\hline Small ( $\leq 4$ persons) & 14 & 23.3 \\
\hline Medium (5-7 persons) & 44 & 73.3 \\
\hline Large ( $\geq 8$ persons) & 2 & 3.3 \\
\hline Total & 60 & 100.00 \\
\hline Minimum-Maximum & \multicolumn{2}{|c|}{$3-9$} \\
\hline Average \pm Standard deviation & \multicolumn{2}{|c|}{$5.25 \pm 1.230$} \\
\hline \multicolumn{3}{|c|}{ Income per capita per month (Rupiah) } \\
\hline Poor $(\leq 291474)$ & 11 & 18.3 \\
\hline Not Poor (>291 474) & 49 & 81.7 \\
\hline Total & 60 & 100.0 \\
\hline Minimum-Maximum & \multicolumn{2}{|c|}{$142857-1700000$} \\
\hline Average \pm Standard deviation & \multicolumn{2}{|c|}{$547946 \pm 326189.012$} \\
\hline
\end{tabular}

\section{Family Function}

The results showed that almost all samples were categorized into families with good family function. It means that they often implemented family function in family (Table 2).

Table 2 Family distribution based on categories of family functions

\begin{tabular}{|c|c|c|c|c|c|c|c|c|c|}
\hline \multirow{3}{*}{ Category } & \multicolumn{9}{|c|}{ Family function* } \\
\hline & 1 & 2 & 3 & 4 & 5 & 6 & 7 & 8 & 9 \\
\hline & $\%$ & $\%$ & $\%$ & $\%$ & $\%$ & $\%$ & $\%$ & $\%$ & $\%$ \\
\hline $\begin{array}{l}\mathrm{Bad} \\
(0.00-33.33)\end{array}$ & 0.0 & 0.0 & 0.0 & 0.0 & 1.7 & 0.0 & 1.7 & 0.0 & 0.0 \\
\hline $\begin{array}{l}\text { Moderate } \\
(33.34-66.67)\end{array}$ & 1.7 & 16.7 & 8.3 & 18.3 & 58.3 & 1.7 & 66.7 & 15.0 & 5.0 \\
\hline $\begin{array}{l}\text { Good } \\
(66.68-100.00)\end{array}$ & 98.3 & 83.3 & 91.7 & 81.7 & 40.0 & 98.3 & 31.7 & 85.0 & 95.0 \\
\hline Total & 100.0 & 100.0 & 100.0 & 100.0 & 100.0 & 100.0 & 100.0 & 100.0 & 100.0 \\
\hline Min-Max & $\begin{array}{l}65.0- \\
100.0\end{array}$ & $\begin{array}{l}60.0- \\
100.0\end{array}$ & $\begin{array}{l}60.0- \\
100.0\end{array}$ & $\begin{array}{l}55.0- \\
100.0\end{array}$ & $\begin{array}{l}30.0- \\
90.0\end{array}$ & $\begin{array}{l}60.0- \\
100.0\end{array}$ & $\begin{array}{l}30.0- \\
100.0\end{array}$ & $\begin{array}{l}45.0- \\
100.0\end{array}$ & $\begin{array}{l}61.3- \\
93.1\end{array}$ \\
\hline Average \pm SD & $\begin{array}{l}87.8 \pm \\
8.9\end{array}$ & $\begin{array}{l}81.7 \pm \\
11.6\end{array}$ & $\begin{array}{l}86.8 \pm \\
10.9\end{array}$ & $\begin{array}{l}78.2 \pm \\
11.8\end{array}$ & $\begin{array}{l}65.2 \pm \\
13.8\end{array}$ & $\begin{array}{l}94.3 \pm \\
8.7\end{array}$ & $\begin{array}{l}63.3 \pm \\
14.4\end{array}$ & $\begin{array}{l}77.8 \pm \\
12.0\end{array}$ & $\begin{array}{l}79.4 \pm \\
7.6\end{array}$ \\
\hline
\end{tabular}

(*) $1=$ religion; $2=$ social and culture; $3=$ love; $4=$ protection; $5=$ reproduction; $6=$ socialization and education; $7=$ economy; $8=$ environmental development; $9=$ family function

Implementation of religious function, social, culture, love, protection, socialization and education aspect, as well as environmental development aspect was categorized as good. Only the implementation of economicand reproductive 
functions aspects were categorized as moderate. It showed that family did not often perform these functions.

\section{Family Conflict}

The results showed that most family conflicts were categorized as moderate indicating lack of conflict in family. Most conjugal conflicts were categorized low showing no conflict between huband and wife in family. Most conflicts among parents and children were categorized moderate. Conflict between parents and children (15\%) was higher than conjugal conflict (3.3\%) (Table 3).

Table 3 Family distribution based on categories of family conflict

\begin{tabular}{|c|c|c|c|}
\hline Category & $\begin{array}{c}\text { Conjugal conflict } \\
(\%)\end{array}$ & $\begin{array}{l}\text { Parents-children } \\
\text { conflict }(\%)\end{array}$ & $\begin{array}{c}\text { Family } \\
\text { conflict }(\%)\end{array}$ \\
\hline Low (0.00-33.33) & 55.0 & 15.0 & 31.7 \\
\hline Moderate (33.34-66.67) & 41.7 & 70.0 & 63.3 \\
\hline High (66.68-100.00) & 3.3 & 15.0 & 5.0 \\
\hline Total & 100.0 & 100.0 & 100.0 \\
\hline Min-Max & $0.0-73.8$ & $11.5-96.2$ & $4.4-79.4$ \\
\hline Average \pm SD & $34.0 \pm 15.4$ & $49.5 \pm 16.4$ & $39.9 \pm 13.9$ \\
\hline
\end{tabular}

\section{Subjective Well-being}

The results showed an overall subjective well-being in which most families were categorized as moderate and the rest were categorized as low. In addition, two-thirds of total economic aspects were categorized as the lowest compared to the psychological, physical and social aspects. Physical and social aspects were categorized as moderate. Meanwhile, there is no psychological aspects which was categorized as high, but mostly categorized as low and medium (table 4).

Table 4 Family distribution based on categories of family conflict

\begin{tabular}{lrrrrr}
\hline Category & Physic (\%) $\begin{array}{l}\text { Economy( } \\
\%)\end{array}$ & $\begin{array}{l}\text { Psycholog } \\
\text { y }(\%)\end{array}$ & Social (\%) & \multicolumn{2}{c}{$\begin{array}{l}\text { Subjective } \\
\text { well-being } \\
(\%)\end{array}$} \\
\hline Low (0.00-33.33) & 38.3 & 66.7 & 50.0 & 31.7 & 48.3 \\
Moderate(33.34-66.67) & 58.3 & 30.0 & 50.0 & 65.0 & 51.7 \\
High (66.68-100.00) & 3.3 & 3.3 & 0.0 & 3.3 & 0.0 \\
\hline Total & 100.0 & 100.0 & 100.0 & 100.0 & 100.0 \\
\hline Min-Max & $0.0-75.0$ & $0.0-80.0$ & $7.1-60.7$ & $0.0-87.5$ & $11.4-65.7$ \\
Average \pm SD & $35.3 \pm 15.7$ & $23.2 \pm 21.6$ & $32.1 \pm 14.9$ & $39.5 \pm 15.2$ & $33.3 \pm 13.3$ \\
\hline
\end{tabular}

\section{The Influence of Family Characteristics, Family Function and Family Conflict toward Subjective Well-being}

The results showed that Adjusted R Square between variables on the subjective well-being of family was 0.343 . This means that 34.3 percent of the variable affecting subjective well-being of families and the remaining 65.7 percent influenced by other variables outside this study (Table 4). Other variables such as 
financial management (Maghfiroh, 2014), social support, and communication patterns (Muladsih, 2011) also affect subjective well-being of family.

The results of multiple linear regression test indicate the age of husband ( $\beta=$ 0275; $p=0.019$ ) gives significantly positive effect on subjective well-being of family. Family function $(\beta=0287 ; p=0.012)$ gives significantly positive effect on subjective well-being of family. In contrast, the parent-child conflict $(\beta=-$ 0397; $p=0.004)$ gives significantly negative effect on subjective well-being of family. The increase of one unit of husband age would increase subjective wellbeing of family by 0.547 points. The increase of one unit of family function will raise subjective well-being of family by 0.506 points and the increase of one unit of parent-child conflict will decrease subjective well-being of family by 0.322 points (Table 5).

Table 5 Effect of family characteristics, family function, and family conflict to the subjective well-being of family

\begin{tabular}{|c|c|c|c|c|}
\hline \multirow{2}{*}{ Variables } & $\begin{array}{l}\text { Non } \\
\text { coefficient }\end{array}$ & standardized & $\begin{array}{l}\text { Standardized } \\
\text { coefficient }\end{array}$ & \multirow{2}{*}{ Significance } \\
\hline & B & $\begin{array}{l}\text { Std. } \\
\text { Error }\end{array}$ & Beta $(\beta)$ & \\
\hline Constants & -23.365 & 21.284 & & \\
\hline Husband age (year) & 0.547 & 0.225 & 0.275 & $0.019 *$ \\
\hline $\begin{array}{l}\text { Length of husband education } \\
\text { (year) }\end{array}$ & 0.343 & 0.880 & 0.046 & 0.699 \\
\hline Length of wife education (year) & -0.523 & 0.850 & -0.072 & 0.541 \\
\hline Family size (person) & 0.885 & 1.217 & 0.082 & 0.470 \\
\hline Monthly family income (Rp) & $1.692 \times 10^{-6}$ & 0.000 & 0.180 & 0.121 \\
\hline Family function (score) & 0.506 & 0.195 & 0.287 & $0.012 *$ \\
\hline Conjugal conflict (score) & 0.011 & 0.113 & 0.012 & 0.924 \\
\hline Parent-children conflict (score) & -0.322 & 0.108 & -0.397 & $0.004 * *$ \\
\hline $\mathrm{F}$ & & & 4.845 & \\
\hline Sig & & & $0.000^{* *}$ & \\
\hline R Square & & & 0.432 & \\
\hline Adjusted R Square & & & 0.343 & \\
\hline
\end{tabular}

(**) significance on $\mathrm{p}<0.01 ;(*)$ significance on $\mathrm{p}<0.05$

\section{DISCUSSION}

The results showed that husband age affects the subjective well-being of family. The increase of husband age will improve the subjective well-being of family. According to Iskandar et al. (2006), the increasing age will cause the increase of work experience and could be in the top of his career and achieving the highest family income so that it is more than the previous well-being. Lenght of education and income do not influence significantly the subjective welfare. This was caused as much as $81.7 \%$ of income per capita families per month which is not considered poor, although length of husband education $(76.7 \%)$ and wife (70\%) was categorized only six years or graduated from elementary school so that this can improve the subjective well-being in which the family of the husband's increasing age will increase families subjective welfare. The increasing age of a husband will enhance the work experience and make the career reach the peak. 
Moreover, family income can reach the highest so that family welfare can be felt better than before.

Based on family function stated by National Population and Family Planning (2012), the results of this study showed that the higher the family functions are, the more subjective well-being of family will be. These results are consistent with the results of Sopiah (2014) stating that subjective well-being of family was affected by family function. The high implementation of family function aspects are suspected because family developed cognitive abilities so that can sustain a family destination. According to Zamani et al. (2014), the better cognitive abilities are, the better family function and resilience of family will be. Meanwhile, well-being of family is the output of the resilience family which detemined by family function so that the viability can be maintained to achieve family goals (Sunarti, Hernawati, \& Nuryani, 2009).

High achievement on aspects of religious function, social, culture, love, protection, socialization and education, as well as the environmental development allegedly due to family develop the ability of social connection and relationship among family members. According to Vandeleur et al. (2009), capacity-building of social relations and relation among family members play an important role in serving family function. The low achievement of reproductive function and economic aspects allegedly due to the positive self-concept owned by family members is low. According to Sopiah (2014), a person who has positive selfconcept will lead to a positive perspective on life in families so that family function can be implemented optimally. Self-concept will give effect to the process of thinking, feeling, desire, and purpose of one's life (Clemes \& Bean, 2001, as cited in Sopiah, 2014).

Goddess and Basti (2008) argued that marriage requires adjustment to the demanding role and responsibilities of each member in the family in order to avoid disputes and divorce. Puspitawati (2012) suggests some examples of conflict in the family, namely the conflict between the roles of husband and wife as well as conflicts among parents and children. The results showed that the higher the parents-teenagers conflict will result in the decline of subjective wellbeing of family. This is in line with the opinion of Roskos, Handal, and Ubinger (2010) that the lower the family conflict resolution, the higher the family conflict and the lower life satisfaction felt by the family.

The results also showed that conflict among parents and teenagers frequently happened than conflicts between spouses. This is in line with the statement of Lestari (2012) that the level of conflict between parents and children is higher than between husband and wife. Goddess and Basti (2008) concluded that the distance between spouses can affect the intensity of the conflict between husband and wife like the husband and wife who lives in distance had less conflict than those who living together.

Problems in the conflict among parents and teenagers were common behavior problems of children. Conflict among parents and teenagers will cause the difficulties of them in adapting such as high levels of aggressive children (Jaycox \& Repetti, 1993). According to Santrock (2007), there was an increase in conflict among parents and children when children enter early stage of adolescence caused by biological changes during puberty, cognitive changes 
involving increased idealism and logic, as well as the social changes that focus on independence and identity. Many parents assume their teenagers refused standards made by parents so that parents tend to be more assertive and pressed his son to follow the standards of parents.

Common problems in conflict between husband and wife was family's financial problems. These results are consistent with the results of Prihartanti Melinda research (2013), shows that the family economy and children education were important aspects for couples who live in the long distance. The source of conflict in the husband-wife relationship was the economic difficulties in the family (Rachmadani, 2013, as cited in Sari, 2014). Couples who live separetely in long distance does not feel jealous of the presence of other people, because of the mutual trust and most importantly the family needs were fulfilled. Conflict between husband and wife made teenagers depressed so that role of the family is necessary to help resolve the conflict (Unger et al., 2000).

Subjective well-being is a family ideal standard based on oneself satisfaction on well-being which is different for each individual because the criteria are based on themselves (Sunarti, 2013). The results showed that wife tends to be satisfied, but the rest of the family was not satisfied with the subjective well-being of family. Families tend to be satisfied with social well-being aspects rather than the physical, psychological, and economic. It happened when the aspect of family economic function is rarely to be done. Even financial problems became more common than other issues so that the wife was not satisfied eventhough they are trying to manage finance in order to provide family need.

In the aspect of social well-being, wife felt more satisfied than other aspects allegedly due to family and environment that supported it. According to Hurlock (1980), women get their early satisfaction from dedication to others in adulthood and they are not expected to work outside their home, except there are financial circumstances which force him. Wife is satisfied on well-being of physical and psychological aspects because of frequent implementation of the family function. According to Sanchez et al. (2011), the physical and mental well-being is affected by family function.

This study has several limitations, namely: (1) the results and conclusions only apply to the sample chosen because it used a sampling technique in the form of non-probability sampling like purposive sampling; (2) the wife is the respondent, it would be completed, if the husband and their teenager participate as respondents.

\section{CONCLUSION AND RECOMMENDATION}

\section{Conclusion}

In average, the age of husbands and wives was 44 years and 39 years. The average length of education of husbands and wives was six years or equal to elementary school (SD). Husbands mostly work as labor. Wives mostly work as housewife and the rest wife worked as trader and others. In average, husbands work out of town for five weeks. Family which consisted of five to seven people were categorized as large family. The average of family monthly income was 
Rp2.701.667,00 in which the average monthly income of Rp547.946,00 is not considered as poor.

Implementation of family functions was categorized as good which often performed by the family, while the family conflict was categorized as moderate or frequent conflict. The level of subjective well-being was categorized as moderate which equal to wife is satisfied. Husband age, family function, and parentsteenagers conflict affect the subjective well-being of family. Increasing age of husband will improve the subjective well-being of family. The more frequent implementation of family function is, the higher levels of subjective well-being will be. The lower level of parent-children conflict, the higher levels of subjective well-being family will be. The lower level of conjugal conflict, the higher subjective well-being of family will be.

\section{Recommendation}

Based on these results, recommendations are given to the family with migrant husband, namely: (1) The implementation of economic function and reproduction aspects not yet optimal so it's expected that famlily can optimalize both of family function with implementing good financial management and education of reproductive health. Government and universities are expected to disseminate the importance of implementing the family function so that the family can improve the subjective well-being, (2) Conflict between parents and teenagers are more common than conflict between husband and wife, so it's expected the socialization of the important of a good communication between parents and child, and (3) further research could investigate about stress and social support which are suspected influencing the well-being of family with migrant husband.

\section{REFERENCES}

Banovcinova, A., Levicka, J., \& Veres, M. (2014). The impact of poverty on the family system functioning. Procedia-social and behavioral science. 132, 148-153.

Dewi, E. M. P., \& Basti. (2008). Marital conflict and conflict resolution models in couples. Journal of Psychology. 2 (1), 42-51.

Djunaedi, E. (1997). Pattern migrated of Cisanyong Village, Cisanyong District, Tasikmalaya District, West Java: Anthropological study of driving and pulling factors of Cisanyong people to migrate. (Master's thesis). Retrived from http://lib.ui.ac.id/opac/themes/green/detail.jsp?id=78868.

Hurlock, E. B. (2009). Developmental psychology: A life-span approach (Istiwidayanti \& Doedjarwo, Trans.). Jakarta, Indonesia: Erlangga.

Iskandar, Hartoyo, Sumarwan, U., \& Khomsan, A. (2006). Factors that influence family well-being. Retrived from http://repository.usu.ac.id/ bitstream/123456789/18931/1/ikm-des2006-10\%20\%289\%29.pdf

Jaycox, L. H., \& Repetti, R. L. (1993). Conflict in families and the psychological adjustment of preadolescent children. Journal of Family Psychology. 7(3), 344-355. 
Leake, R. S. (2009). Island Princess: Culture migration and its impact on Bawean Island. Retrived from http://www.acicis.edu.au/wp-content/uploads/2015/03/ LEAKE-Rebecca.pdf.

Lestari, S. (2012). Family psychology: planting value and conflict resolution in the family. Jakarta, Indonesia: Kencana Prenada Media Group.

Maghfiroh, S. (2014). Financial management and fishermen family well being recipients BLSM. (Undergraduate thesis). Retrived from http://repository.ipb.ac.id/ handle/123456789/73496.

Melinda, R., \& Prihartanti, N. (2013). The differences in subjective well-being in terms of togetherness of the couple in marriage. (Undergraduate thesis). Retrived from http://eprints.ums.ac.id/25361.

Muladsih, O. R. (2011). Communication pattern, decision making, and family welfare remotely on graduate student of Bogor Agricultural University. (Undergraduate thesis). Retrived from http://repository.ipb.ac.id/ handle/123456789/47437.

National Population and Family Planning. (2005). Profile of Family Collection Data. Jakarta, Indonesia: Author.

Pratiwi, S. A. (2014). The influence of the father; s perception of secondary education and family welfare on education of children in the family investment. (Undergraduate thesis). Retrived from http://repository.ipb.ac.id/ handle/123456789/73447.

Puspitawati, H., \& Herawati, T. (2013). Family research method. Bogor, Indonesia: IPB Press.

Puspitawati, H. (2012). Gender and family: concept and reality in Indonesia. Bogor, Indonesia: IPB Press.

Roskos, P.T., Handal, P. J., \& Ubinger, M. E. (2010). Family conflict resolution its measurement and relationship with family conflict and psychological adjusment. Psychology. 1(5), 370-376. doi:10.4236/psych.2010.15046.

Sanchez, E. R., Penaranda, A. P., Baltar, A. L., Arechaederra, D. P., Marcos, M. A. G., Alonso, M. C. P., \& Ortiz, L. G. (2011). Relationship between quality of life and family function in caregiver. Family Practice. 12(1), 1-7.

Santrock, J. W. (2007). Child Development (Rachmawati Kuswanti M \& A, Trans.). In Hardani W (Ed.). Jakarta, Indonesia: Erlangga.

Sari, D. P. (2014). Conflict and family harmony in the family farmer. (Undergraduate thesis). Retrived from http://repository.ipb.ac.id/ handle/123456789/75090.

Sari, F. P. (2013). The influence of marital conflict and parent-child communication on teenager's personality of working and non-working mother families. (Undergraduate thesis). Retrived from http://repository.ipb.ac.id/handle/123456789/66039.

Sopiah, N. N. (2014). Self-concept, function and well-being of family in the chinese and Betawi race family in Sukasari Village, Tangerang District, Tangerang City. (Undergraduate thesis). Retrived from http://repository.ipb.ac.id/ handle/123456789/69177.

Statistics Indonesia. (2014a). Number and percentage of poor people, poverty line, poverty depth index $(\mathrm{P} 1)$, and poverty severity index (P2) by province, 
September 2014. Retrived from http://www.bps.go.id/ linkTabelStatis/view/id/1488.

Statistics Indonesia. (2014b). Percentage of poor people by city and village in West Java, 2012-2014. Jakarta, Indonesia.

Sunarti, E., Hernawati, N., \& Nuryani, N. (2009). The relationship between the function of adaptation, goal attainment, integration, and system maintenance with family well-being. Journal of Family and Consumer Sciences. 2 (1), 110 .

Sunarti, E. (2013). Family Resilience. Bogor, Indonesia: IPB Press.

Unger, D. G., Brown, M. B., Tressell, P. A., \& McLeod, L. E. (2000). Interparental conflict and adolescent depressed mood: the role of family functioning. Child Psychiatry and Human Development. 31(1), 23-41.

Vandeleur, C. L., Jeanpretre, N., Perrez, M., \& Schoebi, D. (2009). Cohesion, satisfaction with family bonds, and emotional well-being in families with adolescents. Journal of Marriage and Family. 71(5), 1205-1219. doi: 10.1111/j.1741-3737.2009.00664.x.

Widyastuti, A. (2012). Analysis of the relationship between worker productivity and education levels of workers on family well-being in Central Java in 2009. Economic Development Analysis Journal. 1 (1), 1-11.

Zamani, Z. A., Nasir, R., Desa, A., Khairudin, R., \& Yusooff, F. (2014). Family functioning, cognitive distortion and resilience among clients under treatment in drug rehabilitation centres in Malaysia. Procedia-Social Behavioral Science. 140: 150-154. doi: 10.1016/j.sbspro.2014.04.401. 